\title{
MSMES RATTAN BUSINESS MODEL IN PULANG PISAU REGENCY IN SUPPORTING SUSTAINABLE MANAGEMENT OF PEATLAND ECOSYSTEMS
}

\author{
Widyastutik $^{*}$, Deden Djaenudin**), and Sahara*) \\ *) Department of Economics, Faculty of Economics and Management, IPB University \\ Jl. Agatis, IPB Dramaga Campus, Bogor 16680, Indonesia \\ ${ }^{* *}$ Research Center for Social Economic Policy and Climate Change, Ministry of Environment and Forestry, \\ Republic of Indonesia \\ Jl. Gunung Batu No. 5, Bogor 16610, Indonesia
}

\begin{abstract}
In supporting the sustainable management of the peat ecosystem, the participation of the community around the peat ecosystem is needed. The challenge faced is how to encourage local communities with sustainable peatland-based economic activities. Rattan is one of the paludicultural commodities that is endemic to habitat that can grow on peatlands and has economic potential and even export orientation. This study aims to [1] analyze the development of a rattan handicraft business model in peatlands [2] Evaluation of the rattan handicraft business on peatlands. The types of data used in this study are primary and secondary. Secondary data were obtained through interviews and FGDs with respondents of MSMEs Rattan in Gohong, Garung and Pilang Villages, Pulang Pisau Regency, and related agencies. The analytical method used is the business model canvas (Business Model Canvas) and the NPV business valuation, IRR, BC Ratio and Payback Period. Based on the analysis, 9 elements of the canvas business were identified as several critical points in the existing canvas business model of rattan MSMEs in Pulang Pisau Regency. Some of these critical points include: [a] technical aspects of improving skills, especially making up to date rattan handicraft designs which still need guidance, [c] access and market reach that are still not broad, (d) difficulties in access to banks (e) constraints on export procedures, (f) ability to do branding. Business valuation shows a positive Net Present Value which indicates that this business has a significant economic impact with a high positive value. IRR has a value greater than the rate of return, Net B / C above 1 and a payback period that is less than the life of the project (assuming the project life is 5 years).
\end{abstract}

Keywords: business model canvas, business valuation, rattan MSMEs, peat

\begin{abstract}
Abstrak: Dalam mendukung pengelolaan ekosistem gambut berkelanjutan diperlukan peran serta masyarakat yang ada di sekitar ekosistem gambut tersebut. Tantangan yang dihadapi adalah bagaimana mendorong masyarakat lokal dengan kegiatan ekonomi berbasis lahan gambut berkelanjutan. Rotan merupakan salah satu komoditas paludikultur yang secara endemik memiliki habitat dapat tumbuh di lahan gambut dan memiliki potensi ekonomi bahkan orientasi ekspor. Penelitian ini bertujuan [1] Menganalisis pengembangan model bisnis kerajinan rotan di lahan gambut; [2] Menganalisis kelayakan usaha kerajinan rotan di lahan gambut. Jenis data yang digunakan dalam penelitian ini adalah primer dan sekunder. Data primer diperoleh melalui wawancara dan FGD dengan responden UMKM Rotan di Desa Gohong, Garung dan Pilang Kabupaten Pulang Pisau serta instansi terkait. Metode analisis yang digunakan adalah model bisnis kanvas (Business Model Canvas) dan kelayakan bisnis NPV, IRR, BC Ratio dan Payback Period. Berdasarkan hasil analisis, 9 elemen bisnis kanvas diidentifikasi beberapa titik kritis pada model bisnis kanvas eksisting pada UMKM rotan di Kabupaten Pulang Pisau. Beberapa titik kritis tersebut diantaranya: [a] aspek teknis peningkatan ketrampilan terutama membuat desain kerajinan rotan yang up to date yang masih perlu memperoleh pembinaan, [c] akses dan jangkauan pasar yang masih belum luas, (d), kesulitan akses pada perbankan (e) kendala prosedur ekspor, (f) kemampuan melakukan branding. Kelayakan bisnis menunjukkan Net Present Value bernilai positif yang mengindikasikan bahwa usaha ini memiliki dampak ekonomi yang cukup signifikan dengan nilai positifyang tinggi. IRR memiliki nilai lebih besar dari tingkat pengembalian, Net B/C di atas 1 dan Payback period yang kurang dari umur proyek (diasumsikan umur proyek 5 tahun).
\end{abstract}

Kata kunci: model bisnis kanvas, kelayakan usaha, umkm rotan, gambut

\footnotetext{
${ }^{1}$ Corresponding author:

Email: widyastutik@apps.ipb.ac.id.
} 


\section{INTRODUCTION}

Peat ecosystems are formed from the interaction and unity between the substrate (organic soil), water (hydrology) and vegetation as a whole and solidly. Peat ecosystems have important environmental values and services such as controlling and controlling hydrology, carbon sinks and sequesters, sources of net plasma and biodiversity and other socioeconomic benefits. Despite having important values and functions, the peatland ecosystem in Indonesia is facing the threat of deforestation and degradation due to unwise management and use that is unsustainable. Deforestation and peat degradation have an impact on hydrological disturbances, decreased forest cover, peat subsidence, increased fire vulnerability, increased emission of greenhouse gases, loss of biodiversity and other socio-economic conditions (Putri, 2017).

As an effort to prevent, handle, and control the destruction of peatlands due to forest and peatland fires and other factors, the government has launched peatland restoration with a target of two million hectares. The peat restoration effort is carried out using three approaches, namely (1) rewetting dry peatlands (rewetting); (2) restoration of land cover by planting native species in areas with a protected function or with other types of plants that are adaptive and have economic value in cultivation functions (revegetation); and (3) revitalizing community livelihoods (revitalization). All three approaches are aimed at restoring degraded forests and peatlands in the long term. The peat that is the target of restoration is land that was burned in 2015 and peat domes that have been opened and degraded (Yuliani, 2018).

In the context of restoring forests and peatlands through replanting, the government encourages the application of paludiculture to grow crops of economic value for local communities on peatlands without abandoning the principle of conservation. The application of paludiculture also strongly supports the direction of government policies to increase food security in addition to other agricultural commodities such as fisheries and horticulture. It is possible to use peatlands to support national food security through the development of paludiculture-based agriculture. Peatland resources are quite extensive and in fact there have been various uses by both the community and the corporation.
One of the provinces in Indonesia that has a large area of peatland is Central Kalimantan, which is around $4,733,540$ ha or $30.80 \%$ of the total area (Ramdhan, 2017). Peatlands in Central Kalimantan Province are distributed into 35 Peat Hydrological Units or KHG which are geographically between 110o45'-115o15 'East Longitude and 1015'- 3o45' South Latitude. KHG in Central Kalimantan Province is included in about 67 sub-districts in 11 (eleven) districts / cities, namely South Barito District, East Barito, Kapuas, Katingan, West Kotawaringin, East Kotawaringin, Lamandau, Pulang Pisau, Sukamara and Seruyan District and Palangka Raya City. (http://pkgppkl.menlhk.go.id/ v0/kesatuan-hidrologis-gambut-nasional-skala-1250$000 /)$.

Based on the area of the function of the peat ecosystem in each district / city in Central Kalimantan province, the largest proportion of the Peat Ecosystem Cultivation Function (FBEG) is found in East Kotawaringin Regency, namely 362,271 ha (17.01\%). Meanwhile, the largest proportion of the Peatland Ecosystem Protected Function (FLEG) is in Pulang Pisau Regency, covering an area of $573,483 \mathrm{Ha}(22.02 \%)$. The potential of Pulang Pisau Regency in utilizing peatlands through paludiculture development, seen from the availability of land resources, which is still wide open. The total area of potential land for development in Pulang Pisau Regency is 137,510 hectares. In addition, the potential of Pulang Pisau Regency from the aspect of demographics and human resources is also quite supportive. The contribution of the total population working in the agricultural sector (agriculture, plantation, and fisheries sub-sector) is 29,856 people out of a total population of 126,657 people or around $23.57 \%$. This is also supported by the composition of the population that is dominant at working or productive age in the age range of 15-64 years as much as $68.29 \%$ (http://pkgppkl.menlhk.go.id/ v0/kesatuan-hidrologis-gambut-nasional-skala -1250$000 /$ ). To increase the effectiveness of sustainable peat ecosystem management requires strong support from the participation of the community around the peat ecosystem. The challenge faced is how to sustain their livelihoods and cultural practices in the short term. It is therefore important not only to assess the environmental benefits of peat conservation, but also to provide local communities with sustainable peatlandbased economic activities. 
Previous studies on peatland paludiculture were more about agroforestry development models, including the study by Harun (2011). Harun developed a swamp jelutong-based agroforestry development model to rehabilitate peatlands. Another model is more focused on farming, namely Irawan and Maftu'ah (2014) developing a farming model on peatland. The results of his research show that food crops and plantations that have the potential to be developed in peatlands include rice, corn (for food crops), tomatoes, eggplant, cabbage, and cucumber (for vegetables), oranges, pineapples, salak, kepok banana (for fruit crops). -buahan), and coconut, rubber, oil palm, areca nut (for plantation crops).

Revitalizing people's livelihoods must be accompanied by the development and implementation of business models based on goods and services produced from paludiculture (Giesen \& Nirmala, 2018; Purnomo \& Puspitaloka, 2020). With the revitalization, the community is empowered to manage peatlands as a place for cultivation, such as sago, pineapple, purun, and other paludicultural crops as well as freshwater fisheries. Thus, the community's dependence on land will decrease and the added value of these commodities can be increased and utilized economically by the community. Types of plants developed on peatlands provide high potential economic benefits, depending on the commodity and available market developments (Giesen \& Nirmala, 2018). One of the paludiculture products that has market potential and even the export market is rattan. Because peatlands are an ecosystem that has environmental functions, it is hoped that the cultivation of paludiculture such as rattan can optimize production without sacrificing environmental functions. It is hoped that an increase in income due to the development of upstream and downstream business models for local rattan commodities will boost people's purchasing power, thereby increasing their access to foodstuffs. Furthermore, food security for people living in peatland ecosystems will be achieved without sacrificing the surrounding environment.

A business model that combines strategy, systems, and management to make it more effective so that it makes it easier for business people to work effectively and according to company goals is the Business Model Canvas. The visualization used in BMC in this study supports MSME rattan to have the same understanding so that it can make it easier to achieve goals. The development of BMC was carried out by Prahalad and
Ramaswamy (2004), Ramaswamy (2008, 2009, 2010) and Vargo and Lusch (2006) which improved the value proposition into value co-creations. This change is based on demands in a more market / demand oriented business. Customer satisfaction must be prioritized, so that value is created not only from the producer side, but also with key partners to satisfy customers. BMC is used in several previous studies such as Marlina, Fahmi and Satria (2018) for the study of the Biofertilizer business model. For the case of smallholders, the study of Ramadanti et al. (2017) used BMC in milk and milk products. So far there has been no research on BMC on rattan products, especially peat rattan. Nyoto (2016), Wijaya and Indriyani (2016) have studied similar products such as wood. Meanwhile, Cidy et al. (2016) focus on BMC of bamboo products. Meanwhile, Kawiji and Setyowati (2013) conducted an MSME analysis of rattan in Sukoharjo Regency using the SWOT method. Some of the initial identifications based on the field survey, rattan is a plant that has been cultivated from generation to generation in Pulang Pisau Regency. Apart from being easy to grow, this plant is also a raw material for making handicrafts in the form of woven rattan. The type of rattan that is widely cultivated is the type of Sigi rattan which is thin and easy to make as a woven material. Field survey in the research location villages (Gohong, Garung and Pilang) Pulang Pisau Regency, only $10 \%$ of rattan farmers do not do processing. As many as $58 \%$ of rattan farmers who do processing for their own crafts without selling to other parties. While the remaining 32\% of rattan farmers sell their crops also process rattan for home industry crafts. This is of course a potential that must be developed considering that rattan is an export-oriented product, especially since there is a policy to prohibit the export of raw rattan, of course an opportunity to increase the added value of rattan which will affect the income of the surrounding community. The government issued a policy prohibiting the export of whole or semi-finished rattan which is classified as follows (1) Divided core (rattan heart), (2) Divided skin, (3) Others such as scrap, rattan powder. This prohibition is stated in MOT 45 of 2019 concerning Prohibited Export Goods. Meanwhile, rattan which is free to export includes furniture, handicrafts, lamps, curtains, and other rattan finished products. This is a form of government support to create added value for forest products. Initial findings show that rattan MSMEs in Pulang Pisau district experience export-related constraints on customs. Apart from that, marketing aspects, production aspects, financing and how to create products that are of interest 
to the market, even become trend setters in the national market and even the international market are still obstacles for rattan MSMEs in Pulang Pisau Regency. Some key activities have not been carried out by rattan MSMEs so that they will affect the sustainability of the MSME's rattan business in Pulang Pisau Regency. The development of the canvas business model in this study will provide information for MSMEs regarding the critical point / gap between the rattan SME business model at the current condition and ideally. This critical point needs to be mitigated by the MSME's ratan itself with the support of related stakeholders involving the central government, local governments, the Ministry of Environment and Forestry, the ministry of other institutions as well as associations and the surrounding community.

Based on the various descriptions in the background, it is rational to conduct research on the Rattan Business Model in Pulang Pisau Regency in Support of Sustainable Management of Peatland Ecosystems. Rattan is a plant that can provide economic value to the community and at the same time protect peatlands. Thus the economic goal of increasing community and environmental form of peatland restoration can be achieved together. Efforts to increase community income in Pulang Pisau Regency do not only focus on the upstream (on-farm) aspect, but on the downstream side through efforts to increase the added value of products by developing processed rattan MSMEs. In this regard, this study aims to [1] analyze the development of a rattan handicraft business model in communities on peatlands; [2] Analyzing the feasibility of rattan MSME businesses in communities on peatlands.

\section{METHODS}

The location of this research is Central Kalimantan Province which is an area that has a large area of peatland, around $30.80 \%$ or an area of $4,733,540$ ha of the total area. Whereas the location sample selection was Garung Village and Pilang Village, Jabiren Raya Subdistrict, and Gohong Village, Kahayang Hilir District, Pulang Pisau Regency, Central Kalimantan Province which were taken purposively with the consideration that Pulang Pisau is one of the Peat Forest Areas (KHG) of about 67 sub-districts in 11 (eleven) regencies / municipalities in Central Kalimantan Province where peatlands are dominant. The time of the research was conducted from October to December 2020.
The data used in this study is a combination of primary and secondary data. Primary data were collected through in-depth interviews using structured questionnaires to business actors with a total number of respondents of 11 rattan processing MSMEs and 40 rattan farmers. Purposive selection of respondents. The survey was conducted in Garung Village, Pilang Village and Gohong Village, Pulang Pisau Regency, Central Kalimantan Province. In addition, Focussed Group Discussions (FGD) were also conducted at the village and district / provincial levels. Resource persons at the FGD were UPT KPHP Kahayan Hilir Unit XXXI, Bappedalitbang Pulang Pisau district, Food Security Office Pulang Pisau Regency, Disperindagkop Pulang Pisau Regency, Community Empowerment Service and Desa Pulang Pisau Regency, Central Kalimantan Province. Secondary data were obtained from the Ministry of Environment and Forestry, the Central Bureau of Statistics, publications of various studies and national and international journals through internet searches.

The data collection technique in this study was by interviewing using a structured questionnaire to all rattan craftsmen in 3 villages (11 respondents) and rattan farmers (40 respondents). Apart from structured questionnaires, FGDs were also conducted at the village and district / provincial levels. The FGD was conducted to obtain information from experts, government agencies $(\mathrm{K} / \mathrm{L})$ as well as to dig deeper into the problems and facilitation needed by rattan MSME business actors in the 3 villages as research location.

To answer the first research objective, namely the development of a business model for peatlands, a canvas business model consisting of 9 elements is used. Osterwalder and Pigneur (2010) designed a model called the Canvas Business Model. Customer segments (customer segmentations) are those who use the services or products of the organization and those who contribute to providing income for the organization.

1) Value co-creations are the relationship between consumers and sellers to create value propositions (value statements) continuously. The concept of value co-creations emerged when Vargo and Lusch (2006) introduced Service Dominant Logic (SDL). The SDL concept focuses on the interaction between producers and consumers in the supply network as well as value creation as parties who co-create value through collaboration between the two. Cocreations place customers as parties who actively 
share to create value or products.

2) Channels (channels), namely elements that state how the organization communicates with its customer segments and convey the value propositions of its business. Communication, distribution and sales channels are all factors that enable a company to interact with its customers. Channels describe interactions with customers and play an important role in the processes experienced by customers.

3) Customer relationships, which are fostering relationships with customers that aim to get new customers (acquisition), retain old customers (retention), and offer old and new products or services to old customers.

4) Revenue streams (revenue streams), or inflow of funds, describes how the organization gets money from each customer segment. This flow of funds is what keeps the organization alive. In essence, there are two types of income, namely those that are transactional (transactions) and those that are in the form of recurring.

5) Key resources, describes the most important assets that determine the successful operation of the business model. These valuable assets enable the organization to deliver value propositions to customers well. Key resources can be physical resources (buildings, vehicles, equipment), money, assets, intellectual property (brands, copyrights, patents, customer databases), and human resources.

6) Key activities, are the core activities that determine the success of a business model. Like key resources, key activities play an important role in realizing value propositions. Not all activities need to be included in this step, but only key activities that really support the success of an organization in delivering the value of a product to customers.

7) Key partners, are partners who work together to operate the organization. Organizations need this partnership for various motives which generally are savings due to not achieving economies of scale, reducing risk, obtaining resources or learning.

8) Cost structure, describes all costs that arise as a result of operating a certain business model. All efforts to realize value propositions through the right channels, key resources, and reliable key activities, costs money. The cost structure is influenced by the company's strategy, whether it prioritizes low costs or prioritizes maximum results.
In this research, it will be obtained an overview of the 9 elements of the canvas business model on rattan MSMEs. Apart from the current conditions, this research will develop an ideal canvas business model. The gaps between the 9 elements in the canvas business according to the current conditions will ideally be identified. Based on the results of the gap analysis between the 9 elements of the current and ideal canvas business model, an achievement strategy will be formulated. Furthermore, the business feasibility method is also used to see the potential for increasing income from managing the canvas business model in supporting sustainable peatland ecosystem management for the socio-economic conditions of the surrounding community. The business feasibility methods are Net Present Value (NPV), Internal Rate of Return (IRR), Net Benefit Cost Ratio (Net B / C Ratio), and Payback Period.

\section{a. Net Present Value (NPV)}

NPV is the net benefit received over the life of the project at a certain discount rate. NPV aims to sort the alternatives selected because of the constraints on the cost of capital. The project is declared useful if the NPV is greater than zero. If the NPV is equal to zero, the refundable costs are equal to the project. In this condition, the project is neither profitable nor loss. If the NPV is less than zero, the project cannot generate worth the costs used. In this condition the project is not feasible (Gray et al. 1992). The formula for NPV is as follows (Keown, 2001).

\section{$N P V=\sum \frac{\text { ACFt }}{(1+k)^{t}-10}$}

Description: ACFt (Annual cash flow after tax on $\mathrm{t}$ period); k (returning rate); IO (Innitial Expense); $n$ (project length).

\section{b. Internal Rate of Return (IRR)}

IRR is the interest rate which shows the average annual internal rate of return of the investing company. IRR reflects the maximum interest rate that can be paid by the project for the resources used. A project is said to be feasible if the IRR is greater than the discount rate.

$$
\sum_{t=1}^{n} \frac{\text { ACFt }}{(1+\text { IRR })} t-10
$$


Decision Criteria: If IRR $>=$ the required rate of return, the project is accepted. If IRR $<$ the required rate of return, the project is rejected.

\section{c. Net Benefit Cost Ratio (Net B/C Ratio)}

Net B / C Ratio is the amount of additional benefits for each additional cost of one unit. Net B / C Ratio is obtained from the comparison between the present value of the positive net benefits and the negative present value of the net benefits. The project is said to be feasible if the Net B / C Ratio is greater than one.

\section{d. Payback Period}

Payback Period is an assessment of the feasibility of a project by measuring the period of return on investment. The faster the payback period for investment, the better the project is financed.

$$
\mathrm{PI}=\sum_{\mathrm{t}=1}^{\mathrm{n}} \frac{\mathrm{ACFt}}{(1+\mathrm{k})} / 1 \mathrm{O}
$$

\section{Hypothesis}

- There is a gap between the existing canvas business model and the ideal canvas business model for Rattan MSMEs in Pulang Pisau Regency in supporting the management of the peatland ecosystem.

- Net Present Value and positive IRR, Net B / C above 1 and Payback period less than the project life (assuming the project age is 5 years).

\section{RESULT}

One of the commodities in peatlands, which has high economic value, because it is an export product, is rattan which is processed into various handicrafts. Indonesia is the third country for the export of rattan and rattan products to the world, which is $6.11 \%$, while China is in the first place in exporting rattan and rattan products to the world at $45.15 \%$ and Vietnam is in the second place, which is $12.49 \%$.

\section{MSME's Rattan Business Model in Supporting Sustainable Management of Peatland Ecosystems in Pulang Pisau Regency}

Based on the survey results, only $10 \%$ of rattan farmers do not process or directly sell all of their crops. As many as $58 \%$ of rattan farmers who do processing for their own crafts without selling to other parties. And $32 \%$ of rattan farmers who sell their crops and also process rattan for home industry crafts. Rattan craftsmen in the villages of Gohong and Garung work on rattan crafts due to the abundant availability of raw materials in nature. This is the reason $71.15 \%$ of respondents become rattan craftsmen. The existing rattan has been developed by the community to be processed into various handicrafts. Market guarantees are also the reason for $32.69 \%$ of craftsmen because the handicrafts produced already have markets outside the province and outside the island, and even become souvenirs for tourists who visit directly to the village. The reason for the ease of effort was responded to as much as $42.31 \%$ because they already have hereditary skills. Meanwhile, the other $57.69 \%$ felt that rattan handicrafts were not easy to cultivate because they required special skills. Another reason is more in the presence of additional income for the craftsmen. The current BMC model (existing conditions) for the business of processing rattan into handicraft products in the Pulang Pisau Regency's MSMEs is as follows (Figure 1).

Based on the current state of the canvas business model, an ideal business model for rattan handicrafts is compiled in the Pulang Pisau Regency MSME. The development of the ideal canvas business model for rattan handicraft products in Pulang Pisau Regency is one of the strategies to increase competitiveness so as to boost exports of Indonesian rattan handicraft products. Based on the ideal canvas business model and existing conditions, there is a critical point. Fulfilling the critical point of each of the 9 elements of the canvas business model is a business model development strategy that can increase the production and income of Rattan MSMEs in Pulang Pisau Regency.

In detail, one by one we will describe the ideal canvas business model for Pulang Pisau Regency, which is a paludicultural forest product to support a sustainable peatland ecosystem.

\section{Value co-creations}

The value creation of rattan processing craftsmen in Pulang Pisau Regency, Central Kalimantan is to produce unique, quality local rattan processed products according to market trends, both in shape, size, motif, design, color, and strength at competitive prices. 
The story behind the process that is an advantage for processed rattan products from Pulang Pisau Regency is that the raw material for rattan handicrafts comes from rattan cultivation which supports the peatland ecosystem in a sustainable manner.

\section{Customer Segments}

Rattan craftsmen can do customer segmentation, which is a strategy in differentiating customers into certain groups based on the type and model of craft needed. This strategy can maximize sales potential because knowledge of the types and models of rattan handicrafts requested by each customer group can help rattan craftsmen in meeting the demands of their customers. Ideally, rattan craftsmen should have the following consumer segments:

- Households / Government Agencies / Companies. Benchmarking of batik craftsmen in Malang, collaborating with automotive companies as customer segments. Batik from MSME's handicrafts is a souvenir for company customers. The results of rattan handicrafts in the form of bags and home decorations can be a souvenir for corporate customers.
- Regional traders: these traders play a role in distributing rattan handicrafts to rattan product markets in the provincial scope. Regional traders also fulfill the demand for souvenir shops serving domestic and foreign tourists who come to Kalimantan. Various handicraft products made of rattan are sold in the form of mats, hats, bags, home decorations and even rattan chairs.

- Inter-island traders: these traders play a role in distributing rattan handicrafts to traders or rattan handicraft markets outside the island.

- Reseller.

- Domestic and foreign tourists.

- Exporters: the need for processed industries lies in the continuity of supply which is relatively constant and with large volumes. Often the design is determined by the exporter

- Importers: the need for processed industries lies in the continuity of supply which is relatively constant and with large volumes. As with exporters, importers also often decide on the design, material combination (with leather / cloth) and coloring for rattan handicraft products (for example natural coloring).

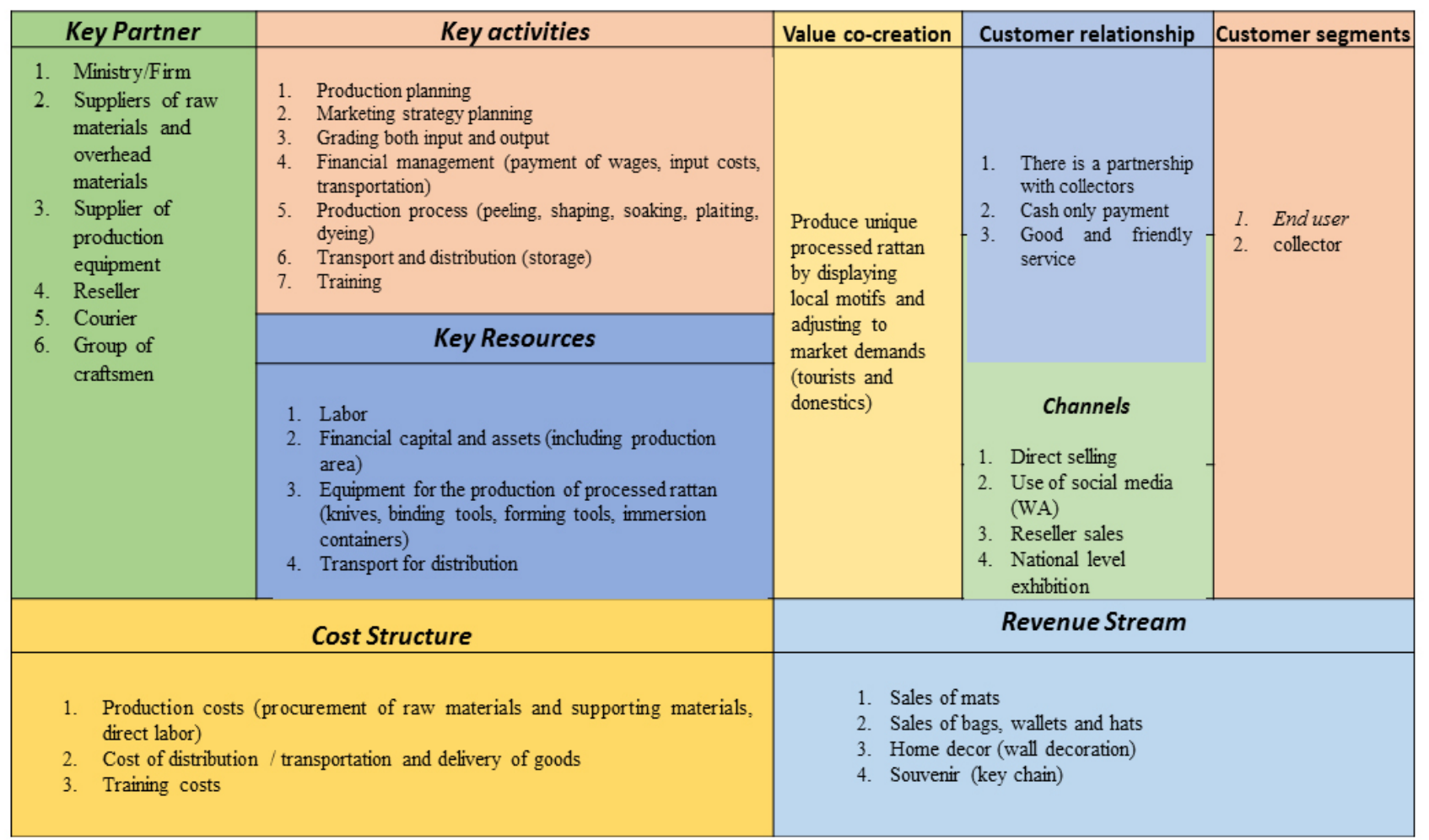

Figure 1. The rattan MSME business model of Pulang Pisau Regency: existing conditions 


\section{Customer Relationships}

To maintain consumer loyalty, rattan craftsmen must establish relationships with customers. So customer relationships are fostering relationships with customers, through various activities, communications or certain services to customers. Some of the activities or services that rattan craftsmen need to do to maintain loyalty or get customers: Guarantee the quality and continuity of rattan handicraft production according to customer demand; There is a written contract or commitment of both parties; Ease of payment methods (cash and noncash) and delivery of goods; Good communication and follow-up if there are complaints/complaints; Aftersales service in the form of delivery of rattan handicrafts to consumers.

\section{Channels (Channels)}

The channel is a medium for rattan craftsmen to convey the value co-creations they have to customers. The goal is that rattan craftsmen can increase their potential customers. The following are media that farmers can use to convey value co-creations: Conventional channels include collective marketing channels through farmer groups (Poktan), Gapoktan, KUB, KUPS or cooperatives; Internet, social media, marketplaces, and websites; Domestic and international exhibitions.

\section{Key Resources}

Key resources are the main assets that rattan craftsmen need to have in orderto ensure that theirbusiness activities can run well. The following are the key resources a rattan craftsman needs to have: A skilled workforce; Financial capital and assets (including production areas); Good quality rattan raw materials; Supporting raw materials (eg. synthetic leather, zippers for bags, wood, etc.); Equipment to produce processed rattan (knives, pulping machines, ovens / streamers, binding tools, forming machines, immersion containers, firing nails); Transport for distribution; Digital information technology infrastructure; Supporting infrastructure for telecommunications and transportation; Gallery / workshop / showroom.

\section{Key Activities}

Several key activities are required for rattan craftsmen so that the productivity of rattan products is high.
Following are the key activities that a rattan craftsman must do to go well: a) Production planning; Planning a marketing strategy; Grading both input and output; Financial management (payment of work wages, input costs, transportation); Production process (peeling, shaping, soaking, plaiting, dyeing); Transportation and distribution (storage); Training.

\section{Key Partners}

The key partners of rattan craftsmen are parties such as ministries/institutions/institutions or individuals who can assist craftsmen, especially those related to cost savings/efficiency, in doing business. The need for stakeholder support related to this is in line with the research of Kawiji and Setyowati (2013). The following are the key partners that craftsmen need to make in running their business: District/Provincial Government; Ministries / Institutions (KLHK, Ministry of Agriculture, Ministry of Industry, Ministry of MSMEs and Cooperatives, Ministry of Trade); Owner of the premises; Suppliers of raw materials and auxiliary materials; Production equipment suppliers; Craftsmen group, KUB, KUPS; Cooperatives, BUMDES; Financing Institutions; Transport/distribution service providers; Reseller; Importers; Exporters; NGOs/ NGOs/Donors; Academics/research institutes / training institutes; BSN; Curator;

\section{Cost Structure}

The assumption of the ideal cost structure of the rattan handicraft business in this canvas business model is based on benchmarking the rattan handicraft business in other regions, in this case MSMEs in West Java which have been export oriented. For the purposes of identifying the cost structure in this study, modifications have been made to rattan MSMEs in the villages of Gohong, Pilang and Garung, Pulang Pisau Regency. The cost structure is structured as follows: The handicraft business produces a wide variety of products including mats, bags, hats, wall hangings, and key chains; Costs incurred other than investment in equipment such as electric sewing machines, manual sewing machines, hides, large knives, small knives, pans and jujuk; Costs of rattan raw materials, supplies such as glue, synthetic leather, croton, and leather; Labor costs. Table 1 shows the cost structure of the rattan handicraft business which is an investment in equipment where the economic age is 3 years. 


\section{Revenue Streams}

The flow of income from the rattan handicraft business is to produce a wide variety of rattan products. Craftsmen can charge prices for rattan handicraft products based on Table 2. With the total production of each as presented in Table 2, the revenue from the sale of rattan handicraft products in year 1 amounted to Rp.413,700,000.00 while the cost was Rp.410,841,667.00, so in the first year you already received a profit of Rp.2.853.333,00.

Based on this analysis, it can be concluded that the rattan handicraft business in the villages of Gohong, Pilang and Garung can improve community welfare where in the value chain this business consists of rattan farmers, people who work in rattan farming, people who work in handicraft businesses. rattan, including inter-island resellers and traders will benefit from this business activity.

The revenue calculation comes from the sale of dried rattan stalks at a price of Rp25,000 / bunch. Because farmers sell to craftsmen or traders between islands in a tie unit. Each year as many as 9,600 bunches are produced. It is assumed that the sales are relatively the same, then the income each year is also the same, namely Rp240,000,000.00. Profit for the first year amounted to Rp51,837,500.00 as well as in the second year, however, there was a slight decrease in profit in the third year due to an increase in depreciation expense due to additional equipment owned. The following is a summary of the elements of the ideal rattan MSME Canvas Business Model which is presented in chart form (Figure 2).

Table 1. MSME's rattan handicraft equipment costs

\begin{tabular}{|c|c|c|c|c|c|c|c|}
\hline Cost component & $\begin{array}{l}\text { Total } \\
\text { (unit) }\end{array}$ & $\begin{array}{l}\text { Price per } \\
\text { unit }(\mathrm{Rp})\end{array}$ & $\begin{array}{c}\text { Acquisition } \\
\text { Value of Assets }\end{array}$ & $\begin{array}{c}\text { Economic } \\
\text { age }\end{array}$ & $\begin{array}{c}\text { Depreciation } \\
\text { Year I (Rp) }\end{array}$ & $\begin{array}{c}\text { Depreciation } \\
\text { Year II (Rp) }\end{array}$ & $\begin{array}{l}\text { Depreciation } \\
\text { Year III (Rp) }\end{array}$ \\
\hline $\begin{array}{l}\text { Electric sewing } \\
\text { machine }\end{array}$ & 4 & 8.000 .000 & 32.000 .000 & 3 & 10.666 .667 & 10.666 .667 & 10.666 .667 \\
\hline $\begin{array}{l}\text { Manual sewing } \\
\text { machine }\end{array}$ & 1 & 2.500 .000 & 2.500 .000 & 3 & 833.333 & 833.333 & 833.333 \\
\hline Jangat & 2 & 50 & 100 & 3 & 33.333 & 33.333 & 33.333 \\
\hline Big knife & 2 & 150 & 300 & 3 & 100 & 100 & 100 \\
\hline Small knife & 2 & 50 & 100 & 3 & 33.333 & 33.333 & 33.333 \\
\hline Pan & 2 & 150 & 300 & 3 & 100 & 100 & 100 \\
\hline Jujuk & 3 & 25 & 75 & 3 & 25 & 25 & 25 \\
\hline Total & & & 35.375 .000 & & 11.791 .667 & 11.791 .667 & \\
\hline
\end{tabular}

Table 2. Rattan Handicraft Business Income

\begin{tabular}{lccrrrr}
\hline \multicolumn{1}{c}{ Product } & Volume & Unit & Price per unit (Rp) & $\begin{array}{c}\text { Depreciation } \\
\text { Year I (Rp) }\end{array}$ & $\begin{array}{c}\text { Depreciation } \\
\text { Year II (Rp) }\end{array}$ & $\begin{array}{c}\text { Depreciation } \\
\text { Year III (Rp) }\end{array}$ \\
\hline Sales revenue & & & & & & \\
Mat & 120 & Leaf & 1.000 .000 & 120.000 .000 & 132.000 .000 & 145.200 .000 \\
Bag & 800 & pcs & 300.000 & 240.000 .000 & 264.000 .000 & 290.400 .000 \\
cap & 400 & pcs & 100.000 & 40.000 .000 & 44.000 .000 & 48.400 .000 \\
Wall decoration & 50 & pcs & 250.000 & 12.500 .000 & 13.750 .000 & 15.125 .000 \\
Key chain & 80 & pcs & 15.000 & 1.200 .000 & 1.320 .000 & 1.452 .000 \\
& & & & 413.700 .000 & 455.070 .000 & 500.577 .000 \\
\hline
\end{tabular}




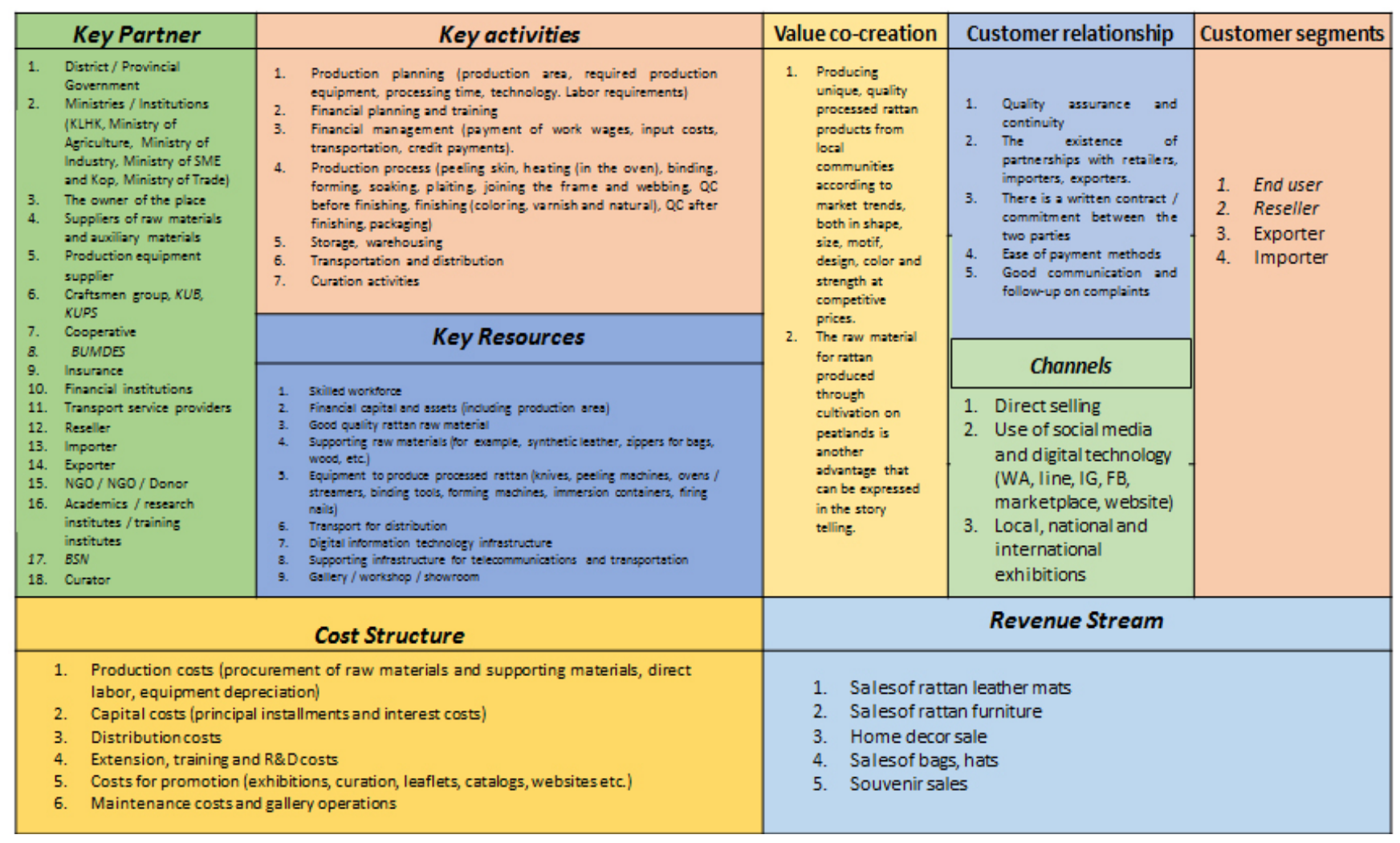

Figure 2. Pulang Pisau MSME's rattan business model: ideal conditions

\section{Business Feasibility Analysis of Rattan Handicraft MSME in Pulang Pisau Regency}

The rattan handicraft business is carried out as a strategy to increase the added value of rattan as well as income for rattan farmers who have started processing rattan stems, which of course requires a lot of investment. Based on the results of interviews with rattan craftsmen, the investment needed in the business is electric sewing machines, manual sewing machines, hides, large knives, small knives, pans, and jujuk. The investment value is Rp35,375,000 in the first year only.

The handicraft product that requires the rawest material for rattan is mats so that the selling price/unit is the highest among the rattan handicraft products produced, reaching $\mathrm{Rp} 1,000,000$. The second highest price is for bag products with a selling price of Rp300,000 per unit. This is related to a fairly complicated process. Likewise, wall decoration products are also quite expensive with a price/unit of $\mathrm{Rp} 250,000$.

The profit generated from this rattan handicraft business is increasing every year, this is in accordance with the sales growth of $10 \%$ per year. With receipts from product sales in year 1 amounting to Rp.413,700,000 while costs amounting to $\mathrm{Rp} 410,841,667$, in the first year you already have a profit of Rp. Based on this, it is a temporary conclusion that this rattan handicraft business can improve the welfare of the community where in the value chain this business consists of rattan farmers, people who work in rattan farming, people who work in rattan handicraft businesses, including resellers and traders between the island will benefit from this business activity.

As with other businesses, to be able to calculate the value of the business eligibility criteria, a cash flow projection calculation can be performed. This cash flow projection contains a cash inflow component consisting of income from sales, assuming it is made in cash and cash inflows for investment, while the cash outflow component consists of variable costs and fixed costs incurred in the production process. Obtained net cash flow results with a discount factor of $6 \%$ in the first year of negative Rp32,678,459, in the second year it is still negative but smaller than the first year and in the third year it has shown a positive number indicating that this business brings net cash flow value positive (cash inflow is greater than cash out). 
The indicator in business feasibility is a criterion that determines whether the business has an economic impact on society, with net cash flows that have considered positive returns and time value of money. It can be seen in Table 3 that the positive Net Present Value is Rp27,917,004 which indicates that this business has a significant economic impact with a high positive value. Likewise, the value of the internal rate of return (IRR) is $32.95 \%$ and this is a high number, this is because there are products produced from leftover materials (key chains and some wall decorations), which results in low production costs. In addition, the proximity of the raw material sources will also cause minimal transportation costs to obtain rattan raw materials. More briefly, the eligibility criteria for a rattan handicraft business can be seen in Table 8 and all meet the criteria for project acceptance, which means that all criteria indicate that this business has a significant economic impact on the community.

Table 3. Eligibility criteria for rattan handicraft business

\begin{tabular}{lc}
\hline Business Feasibility Indicator & Value \\
\hline Net Present Value (NPV) & Rp27.917.004 \\
Internal Rate of Return (IRR) & $32,95 \%$ \\
Net B/C (PI/Profitability Index) & 1,79 time \\
Payback Period (PP) & 2,32 year \\
\hline
\end{tabular}

\section{Managerial Implication}

To ensure the sustainability of the rattan MSME business in Pulang Pisau district, rattan MSMEs need to strengthen the elements of the canvas business model in current conditions in order to achieve the ideal canvas business model conditions. Rattan MSME business actors in Pulang Pisau Regency need to collaborate with KUB / KUPS to strengthen institutional aspects. Through the KUB / KUPS collaboration, which is identified as a group of key partners, the procurement of inputs (for example superior seeds / seeds), production, distribution and marketing can be carried out in an integrated manner so that the business is sustainable.

Given that the export-oriented MSMEs of Pulang Pisau district are export-oriented, MSMEs must have formal institutions such as cooperatives. The formation of a business that is a legal entity will make it easier for business actors to export. Rattan MSMEs also need to collaborate with related Ministries / Agencies to obtain some training including increasing the variety of designs and motifs of rattan handicrafts, training in business management (finance, marketing strategies, human resources), marketing (training using WhatsApp business, joining marketplaces and branding strategy training) and others, as well as the ability to access export markets.

Alternative financing sourced from village funds can be an option in addition to funding from revolving funds which is managed by the agency that is the key player. The government needs to continue to disseminate and facilitate socialization and facilitation to communities on peatlands regarding the greatest economic benefits in the short to long term related to the development of a rattan handicraft business model on peatlands. Facilitation of internet, telecommunication, and transportation infrastructure in expanding market reach, which are key resource canvas business elements that need to be strengthened so that it will increase the business elements of channel canvas and customer relationships.

Rattan MSMEs, Pulang Pisau Regency, needs to collaborate with the central / local government to build a showcase for rattan MSME products cultivated on peatlands. This peatland product storefront is a media shopping window for domestic and foreign tourists, investors, and business players outside the region and abroad who are interested and interested in products produced by people who do business / business on peatlands.

Rattan MSMEs in Pulang Pisau Regency need to develop channels and build customer relationships with local and private governments to use / consume products / commodities produced on peatlands, including the use of rattan MSME handicraft souvenirs for meeting participants and clients / customers for private companies.

\section{CONCLUSIONS AND RECOMMENDATIONS}

\section{Conclusions}

Based on the results of the analysis of 9 elements of the canvas business, several critical points were identified in the existing canvas business model of rattan MSMEs in Pulang Pisau Regency. Some of these critical points include: (a) technical aspects of improving skills, especially making up to date rattan handicraft designs which still need guidance, (b) access and market 
reach that are still not broad, (c) difficulties in access to banking, (d) constraints on export procedures, (e) ability to do branding. The craftsmen are still doing farming activities down and down, so they still need benchmarking in developing a more integrated business model.

The business feasibility analysis shows a positive Net Present Value which indicates that this business has a significant economic impact with a high positive value. Likewise, IRR which has a value greater than the rate of return, Net $\mathrm{B} / \mathrm{C}$ above 1 and Payback period that is less than the life of the project (assuming the project life is 5 years). The proximity of the raw material sources causes minimal transportation costs to obtain rattan raw materials. This is a comparative advantage that rattan handicraft MSMEs have in Pulang Pisau Regency. By developing an ideal business model, the rattan MSMEs of Pulang Pisau district will increase their production and income so that it will have an impact on the economy of the surrounding community on peatlands.

\section{Recommendations}

Related to the elements in the canvas business model, the key partner that needs to be strengthened by the rattan MSMEs of Pulang Pisau Regency is cooperation with Kelompok Usaha Bersama (KUB)/Kelompok Usaha Perhutanan Sosial (KUPS). Through the cooperation of KUB/KUPS with institutions included in the key player group, procurement of inputs (for example superior seeds/seeds), production, distribution and marketing can be carried out in an integrated manner so that the business can be carried out sustainably. Given that the export-oriented MSMEs of Pulang Pisau district are export-oriented, institutional strengthening for existing groups is to have legal formalities such as cooperatives. The formation of a business that is a legal entity will make it easier for business actors to export. Increasing the role of several technical agencies in providing several trainings to increase the variety of designs and motifs of rattan handicrafts, training in business management (finance, marketing strategies, human resources), marketing (training using WhatsApp business, joining marketplaces and training on branding strategies) and others, as well as the ability to access export markets. In connection with the foregoing, several key activities were identified as critical points for the rattan MSMEs of Pulang Pisau Regency.
Efforts to find other alternative sources of financing need to be a concern considering that formal financial institutions (banks) have a low interest in developing the MSME rattan business in Pulang Pisang Regency. Alternative financing sourced from village funds can be an option in addition to funding from revolving funds which is managed by the agency that is the key player. The government needs to continue to disseminate and facilitate socialization and facilitation to communities on peatlands regarding the greatest economic benefits in the short to long term related to the development of a rattan handicraft business model on peatlands. Facilitation of internet, telecommunication, and transportation infrastructure in expanding market reach, which are key resource canvas business elements that need to be strengthened so that it will increase the business elements of channel canvas and customer relationships. Central/local government facilitation to build storefronts for products that are cultivated on peatlands. This peatland product storefront is a media shopping window for domestic and foreign tourists, investors, and business players outside the region and abroad who are interested and interested in products produced by people who do business/business on peatlands. Encourage local governments and the private sector to use/consume products/commodities produced on peatlands. For example, giving rattan handicraft souvenirs to meeting participants and clients/customers for private companies is one of the efforts to introduce products and at the same time increase the market share of rattan handicraft products.

\section{ACKNOWLEDGMENT}

Research Collaboration Funded by The Ministry of Environment and Forestry, Republic of Indonesia.

\section{REFERENCES}

Cidhy DAT, Baga LM, Djohar S. 2015. Pariwisata kreatif dan kegiatan ekstrakurikuler berbasis bambu dalam pengembangan model bisnis CV Suratin Bamboo. Jurnal Manajemen dan Agribisnis 13(3). http://doi.org/10.17538/ JMA.13.3.227.

Giesen W,Nirmala E. 2018. Tropical peatland restoration report : the indonesian case. (March), 99. https:// doi.org/10.13140/RG.2.2.30049.40808.

Harun MK. 2011. Model pengembangan agroforestri 
berbasis jelutung rawa untuk merehabilitasi lahan gambut. https://docplayer.info/33318635Model-pengembangan-agroforestri-berbasisjelutung-rawa-untuk-merehabilitasi-lahangambut.html. [2020 Oct 1].

Irawan, Maftu'ah E. 2014. Model usahatani pada lahan gambut. Di dalam: Nurida NL, Wihardjaka A, editor. Panduan Pengelolaan Berkelanjutan Lahan Gambut Terdegradasi. http://balittanah. litbang.pertanian.go.id/ind/dokumentasi/ panduan\%20gambut/04irawan_usahatani.pdf. [2020 Oct 1].

Irawan, Neneng L, Nurida, MamatHS.2014. Sumbangan lahan gambut untuk ketahanan pangan, ekonomi rumah tangga, dan devisa negara. Di dalam: Agus F, Anda M, Jamil A, Masganti, editor. Lahan Gambut Indonesia: Pembentukan, Karakteristik dan Potensi Mendukung Ketahanan Pangan. Jakarta: IAARD Press. hlm 189-206.

Kawiji, Setyowati N. 2013. Pengembangan usaha kerajinan rotan (pendekatan action research) studi kasus di UKM Asri Rotan Desa Trangsan, Kecamatan Gatak, Kabupaten Sukoharjo. Jurnal Inovasi dan Kewirausahaan 2(1): 9-18.

Nyoto VB. 2016. Model Bisnis pada CV Fang Yang Wood Menggunakan Business Model Canvas. Agora 4(1).

Marlina Y, Fahmi I, Satria A. 2018. Customer Discovery of Biofertilizer Business (A Lesson From PT PHN Experience). Jurnal Manajemen dan Agribisnis 15(2). https://doi.org/10.17358/ jma.15.2.107.
Putri T. 2017. Pengelolaan Sumberdaya Lahan Gambut di Kubu Raya Kalimantan Barat menuju Lahan Tanpa Bakar. Jurnal Penelitian Agrosamudera $4(2)$.

Prahalad CK, Ramaswamy V. 2004. Co-Creation experience: the next practice in value co creation. Journal of In teractive Marketing 19(3).

Ramadanti A, Daryanto A, Sukardi. 2017. The dairy value chain, inclusive business model, and inclusiveness improvement of Sothern Bandung Diary Cooperative (KPBS) Pengalengan. Jurnal Manajemen dan Agribisnis 14(3).https://doi. org/10.17358/jma.14.3.240.

Ramaswamy V. 2008. Co-creating value through customers' experiences: the nike case. Strategy and Leadership 36(5): 9-14.

Ramaswamy V. 2009. Competing through co-creation: innovation at two companies. Strategy and Leadership 38(5): 22.

Ramdhan M. 2017. Analisis persepsi masyarakat terhadap kebijakan restorasi lahan gambut di kalimantan tengan. Risalah Kebijakan Pertanian dan Lingkungan 4(1): 69-72. http://dx.doi. irg/10.20957/jkekebijakan.v4i.20066.

Vargo SI, Lusch RF. 2004. Evolving to a new diominant logic for marketing. Journal of Marketing 68:117.

Wijaya LE, Indriyani R. 2016. Analisis business model canvas pada CV. Kayu Murni Surabaya. Agora $4(2)$.

Yuliani F. 2018. Implementasi perlindungan dan pengelolaan ekosistem gambutsertapengendalian kebakaran hutan dan lahan. Jurnal Kebijakan Publik 9(1): 1-68. 